DOI https://doi.org/10.30525/978-9934-26-111-4-23

\title{
ЗАГРОЗИ І ШЛЯХИ ПОДОЛАННЯ РИЗИКІВ СТАЛОМУ ВИРОБНИЦТВУ РОСЛИННИЦЬКОЇ ПРОДУКЦЇ̈ ЗА ІНТЕНСИВНИХ ТЕХНОЛОГІЙ ВИРОЩУВАННЯ ПОЛЬОВИХ КУЛЬТУР
}

\author{
Сахненко Д. В.
}

кандидат сільськогосподарських наук,

старший науковий співробітник кафедри інтегрованого захисту та карантину рослин

Наиіональний університет біоресурсів і природокористування Украӥни

\section{Мамчур Р. М.}

кандидат економічних наук, дочент кафедри банківської справи та страхування Національний університет біоресурсів і природокористування Украӥни

Доля М. М.

доктор сільськогосподарських наук, професор, завідувач кафедри інтегрованого захисту та карантину рослин Національний університет біоресурсів і природокористування Украйни м. Київ, Украӥна

В 1992-2021 роках за результатами досліджень у польових сівозмінах удосконалені системи вирощування сільськогосподарських культур щодо наслідків впливу інтенсивних технологій, зокрема дії i післядії до 38 \% застосованих засобів хімізації із негативним впливом на формування та розвиток агроценозів. При цьому, обгрунтовані моделі динаміки, а також комплексна інформація щодо фактичних $\mathrm{i}$ очікуваних змін механізмів саморегуляції організмів у грунті і ценозах в цілому. Це дозволяє оптимізувати виявлені ризики та вразливості культурних рослин, як до змін клімату, так і окремих систем землеробства на рівні регіонів, областей і основних секторів економіки. Ці показники актуалізовані та уточнені за закономірностями у регіонах досліджень із визначенням механізмів, що проявлялися стихійно або за прогнозом багаторічних коливань погоди та кліматичних змін. Встановлено, що сучасні технологічні рівні показників у польових сівозмінах і отримання та обробка інформації з ефективністю понад $85 \%$, узагальнює вплив комплексу погодно-кліматичних та систем землеробства на формування соціально-економічного розвитку та 
стратегії фітосанітарного і екологічного стану сезонних і багаторічних процесів [1, 2, 7].

У зв'язку із цим, нагальним виявилось моделювання і забезпечення поглибленого дослідження впливу діяльності людини на агробіоценоз, зокрема за нових оцінок екологічних та соціально-економічних наслідків змін у часі та просторі.

Першочергового значення набули показники, що забезпечують зниження антропогенного навантаження на агробіоценози i обгрунтування екологічно чистих технологій за нових систем ведення рослинництва. Зокрема, мінімізація обробітку грунту, оптимізація форм і норм систем живлення 3 переходом на рідкі форми добрив, а також заходів захисту польових культур від комплексу шкідників хвороб і бур'янів [2]. Це виявилось пріоритетним напрямом у рослинництві та контролі за внесеними засобами хімізації і побудові новітнього широкомасштабного моніторингу стану агроценозів.

Встановлено, що для побудови ефективної системи моніторингу загрози і розробки необхідних комплексних механізмів контролю високодинамічних змін, а також з метою забезпечення відповідного рівня інвестицій для програмного забезпечення цільових проектів важливим $\epsilon$ використання інноваційних ресурсоощадних систем вирощування сільськогосподарських культур із зменшенням на 57-74 \% хімічного навантаження $[5,6]$. Це дозволяс контролювати, як фітосанітарний (до $43 \%$ ), морфофізіологічний (до $52 \%$ ), так і генетичний (до 27 \%) стан польових культур, при вирощуванні пшениці озимої, сої, нуту, кукурудзи, соняшнику, ріпаку, гірчиці за мінімальної загрози загибелі рослин через посухи.

Вперше, створені технологічні нормативи, щодо контролю особливостей вегетації сільськогосподарських культур із заходами, щодо адаптації до нових погодно-кліматичних умов при використанні високоврожайних сортів і гібридів польових культур, які адаптовані до різких коливань температур повітря і грунту за моделями системного підходу до таких наслідків та адаптації до них у масштабах окремих регіонів [7].

За результатами багаторічних досліджень розроблено фітосанітарно- і еколого-економічний механізм забезпечення контрою рівнів формувань ценозів [2]. Він включає системи контролю механізмів стійкості сільськогосподарських культур до чинників зовнішнього середовища i впливу засобів хімізації на структури механізмів самоуправління у трофічних ланцюгах, а також моніторингу наслідків хімізації за інформаційного забезпечення показників екологічно орієнтованих рівнів експертизи та аудиту маркетингу і страхування посівів сільськогосподарських культур. 
При цьому, на видовому та популяційному рівнях узагальнені показники, щодо оцінювання ресурсів організмів за інтенсивних технологій ведення рослинництва. Здійснені розробки, щодо побудови біологічно-ресурсних балансів із визначенням можливостей їх стійкого використання у регіональному масштабі. Вперше обгрунтовані економічні, соціальні і екологічні інноваційні технологічні рішення і на їх основі складені моделі прогнозу використання агробіоценозів за єдиною інформаційною мережею [2, 3]. Це дозволяє формувати та впровадити концепції здоров'я рослин, а також якісного життя та ефективного використання людського капіталу. Комплексність, при цьому досягається ресурсоощадним використанням агроценозів за органічно відновленими механізмами взаємодій суспільства та угідь.

В запропонованій концепції найважливішим методологічним принципом дослідження виступає єдність за комплексним використанням агробіоценозів, населення і технологій $[2,4,7]$ (рис. 1).

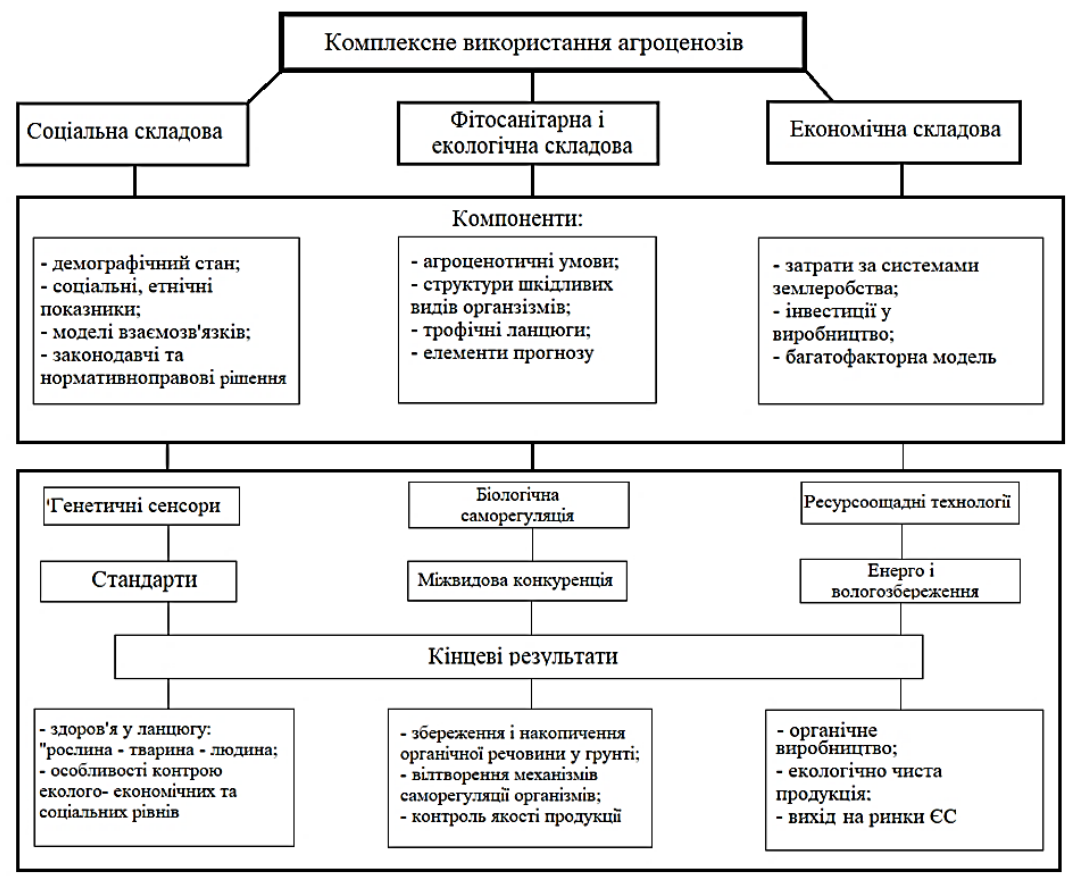

Рис. 1. Структурна модель комплексного природокористування 
Таким чином, в межах комплексного обгрунтованого використання агроценозів, нагальним $є$ оцінка ефективності та наслідків дії і післядії засобів хімізації, що впливають, як на органогенез польових культур, так і накопичення органічної речовини в грунті, виживання організмів $\mathrm{i}$ людини, поєднаних певними відносинами, зумовленими історично мінливими способами матеріальних $\mathrm{i}$ духовних благ, спільною територією.

Це до $85 \%$ обгрунтовує показники, зокрема: економічні, фітосанітарні, економічні та соціальні втрати, що передбачаються та прогнозуються за ступенем ризику зіткнення 3 непередбаченими та небажаними наслідками.

\section{Література:}

1. Ресурсний потенціал регіону : навч. посібник / авт.-упоряд.: М.К. Орлатий, С.А. Романюк, І.О. Дегтярьова та ін. Київ: НАДУ, 2014. $724 \mathrm{c}$.

2. Фітосанітарний моніторинг / М.М. Доля та ін. Київ: ННЦ IАЕ, 2014. 294 c.

3. Красиловець Ю.Г. Наукові основи фітосанітарної безпеки польових культур. Харків, 2010. 416 с.

4. Сонько С.П., Максименко Н.В. Екологічні основи збалансованого приро-докористування в агросфері: навчальний посібник. Харків, 2015. 572 с.

5. Департамент агропромислового розвитку, екології та природних ресурсів. Доповідь про стан навколишнього природного середовища у Вінницькій області (2018р.). URL: http://www.vin.gov.ua/ images/doc/vin/departament-apk/doc/ OperMonitor/Dopov/VinnDopov2019.pdf.

6 Шварц С.С. Экологические закономерности эволюции. Москва: Наука, 1980. 278 с.

7. Stankevych S.V., Vasylieva Yu.V., Golovan L.V. et al. Chronicle of insect pests massive reproduction. Ukrainian journal of ecology. 2019. № 9 (1). P. 262-274. 